\title{
ANALISIS LAPORAN KEUANGAN SEBAGAI ALAT PREDIKSI KEMUNGKINAN KEBANGKRUTAN DENGAN MODEL DISKRIMINAN ALTMAN PADA SEPULUH PERUSAHAAN PROPERTI DI BURSA EFEK JAKARTA
}

\author{
Haryadi Sarjono, ST, MM \\ Dosen Universitas Bunda Mulia, Jakarta \\ E-mail: hsarjono@bundamulia.ac.id
}

\begin{abstract}
Abstrak: Suatu perusahaan didirikan bukan untuk mengalami kebangkrutan, untuk itu diperlukan suatu alat yang dapat digunakan sebagai sistem peringatan dini. Salah satu alat tersebut adalah model Z-Score altman yang berguna untuk memprediksi kinerja keuangan perusahaan, kinerja keuangan yang buruk dapat memicu kebangkrutan. Populasi penelitian ini adalah sepuluh perusahaan properti di Indonesia yang tercatat di Bursa Efek Jakarta (BEJ), dengan menggunakan simple random sampling sebagai teknik pengambilan sampel. Dipilihlah PT. Lippo karawaci Tbk., PT. Summarecon Serpong agung Tbk., PT. Ciputra surya Tbk., PT. Roda Panggon harapan Tbk., PT. Bintang Mitra Semestaraya Tbk., PT. Cipto kontrindoreksa Tbk., PT. Duta Anggada Realty Tbk., PT. Duta Pertiwi Tbk., PT. Kridaperdana Indahgraha Tbk. Dan PT. Lamicitra Nusantara Tbk. Hasil penelitian menunjukkan bahwa diketahui secara teoritis ada 5 perusahaan berada pada kategori bangkrut, ada 2 perusahaan berada di gray area dan 3 perusahaan berada pada kategori sehat. Untuk perusahaan yang sudah berada pada kategori sehat dapat mempertahankan sistem manajemen yang sudah ada, untuk perusahaan yang berada di gray area perusahaan diindikasikan mengalami masalah keuangan yang harus ditangani dengan penanganan manajemen yang tepat dan untuk perusahaan yang masuk kategori bangkrut, manajemen harus secepatnya melakukan penanganan yang tepat jika tidak perusahaan akan mengalami kebangkrutan.
\end{abstract}

Kata kunci : Analisis laporan keuangan, Analisis Z-Score, Analisis kesehatan

\section{PENDAHULUAN}

Kenaikan harga bahan bakar minyak (BBM) dunia oktober 2005 lalu membawa dampak yang cukup besar bagi perekonomian Indonesia terutama pada perusahaan perdagangan eceran. Karena kenaikan BBM dunia ini mengakibatkan tingkat suku bunga ikut meningkat dan inflasi yang tinggi sehingga menyebabkan harga barang-barang eceran juga mengalami peningkatan. Oleh karena itu, penting bagi perusahaan untuk mengevaluasi kinerja keuangan perusahaan unutk mengetahui apakah kinerja keuangan perusahaan sudah menghasilkan laba yang besar bagi pemegang saham.

Analisis rasio keuangan merupakan suatu alternatif untuk menguji apakah informasi keuangan yang dihasilkan oleh akuntansi keuangan bermanfaat untuk melakukan klasifikasi atau prediksi terhadap harga saham dipasar modal. Tingkat kesehatan perusahaan penting artinya bagi perusahaan untuk meningkatkan efisiensi dalam menjalankan usahanya, sehingga kemampuan untuk memperoleh keuntungan dapat ditingkatkan yang pada akhirnya dapat menghindari adanya kemungkinan kebangkrutan (likuidasi) pada perusahaan perdagangan eceran.

Resiko likuidasi terhadap perusahaan perdagangan eceran dapat dilihat dan diukur melalui laporan keuangan, dengan cara melakukan analisis terhadap laporan keuangan yang telah terdaftar di Bursa Efek Jakarta (BEJ). Analisis laporan keuangan merupakan alat yang sangat penting untuk mengetahui posisi keuangan perusahaan serta hasil-hasil yang telah dicapai sehubungan dengan pemilihan strategi perusahaan yang telah dilaksanakan. Dengan adanya latar belakang seperti yang telah digambarkan diatas, maka muncul pertanyaan apakah metode Altman dapat dimplementasikan dalam memprediksi kemungkinan terjadinya kebangkrutan pada perusahaan perdagangan eceran.

\section{PEMBAHASAN}

Pengertian laporan keuangan :

- Munawir (2004:5)

Laporan keuangan adalah dua daftar yang disusun oleh akuntan pada akhir periode untuk suatu perusahaan. Kedua daftar itu adalah daftar neraca atau daftar posisi keuangan dan daftar pendapatan atau daftar laba rugi. Pada waktu akhir-akhir ni sudah menjadi kebiasaan bagi perseroan-perseroan untuk menambahkan daftar ketiga yaitu daftar surplus atau daftar laba yang tak dibagikan ( laba yang ditahan ).

- Sugiyarso(2006:1)

Laporan keuangan (financial statement) merupakan daftar ringkasan akhir transaksi keuangan organisasi yang menunjukkan kegiatan operasional organisasi dan akibatnya selama tahun buku yang bersangkutan.

- Lontoh dan Lindrawati (2004:1)

Laporan keuangan merupakan media komunikasi yang digunakan untuk menghubungkan pihak-pihak yang berkepentingan terhadapa perusahaan. Pentingnya laporan keuangan juga diungkapkan Belkoui bahwa laporan keuangan merupakan sarana mempertanggung jawabkan apa yang telah dilakukan manajer atas sumber daya pemilik. 


\section{Analisis Rasio Keuangan}

- Harahap (2006:297)

Analisis rasio adalah angka yang diperoleh dari hasil perbandingan dari suatu pos laporan keuangan dengan pos lainnya yang mempunyai hubungan yang relevan dan signifikan (berarti).

- Kuswandi (2004:187)

Analisis rasio adalah cara analisa dengan menggunakan perhitungan-perhitungan perbandingan atas data kuantitatif yang ditunjukkan dalam neraca maupun laporan laba rugi.

\section{Analisis Diskriminan}

Emery, Douglas R, Finnerty, John \& Stowe, John $(2004, p 844)$ mengemukakan mengenai analisis diskriminan sebagai berikut:

The discriminant function is of the form $Z=V_{1} X_{1}+V_{2} X_{2}+\ldots .+V_{n} X_{n}$. The Discriminant function transform the indvidual financial ratios into a single discriminant score, or Z-Score. The Z-Score is then used to classify the firms as "bankrupt" or "non bankrupt". In this equation, $V_{1}, V_{2}$, and so forth are discriminant coefficient or weights, and $X_{1}, X_{2}$, and so forth are financial ratios. The Multiple Discriminant Analysis (MDA) technique determines the set of discriminant coefficients, $V_{v}$ that Maximizes the percentage of firms that are correctly classified. The discriminant function is used to calculate a Z-Score for a firm in order to assign it to one of two groups.

Artinya, bentuk dari fungsi diskriminan adalah $Z=V_{1} X_{1}+V_{2} X_{2}+\ldots .+V_{n} X_{n}$. Fungsi diskriminan mengubah bentuk rasio keuangan yang berdiri sendiri ke dalam suatu skor diskriminan tunggal atau Z-score. Z-Score ini kemudian digunakan untuk mengklasifikasikan perusahaan ke dalam kategori 'bangkrut' atau 'tidak bangkrut'. Pada persamaan ini $V_{1}, V_{2}$, dan seterusnya adalah koefisien diskriminan dan $\mathrm{X}_{1}, \mathrm{X}_{2}$, dan seterusnya adalah rasio keuangan.

\section{Rasio keuangan Dalam Analisis Diskriminan Altman}

Rasio keuangan dirancang untuk membantu mengevaluasi laporan keuangan, yaitu untuk mengungkapkan kekuatan dan kelemahan relatif suatu perusahaan dibandingkan dengan perusahaan lain dalam industri yang sama, dan untuk menunjukkan apakah posisis keuangan membaik atau memburuk selama suatu waktu.

Adnan M \& Taufiq M, Jurnal ekonomi \& Auditing. (2005, p189-190) Adapun variabel-variabel atau rasio-rasio keuangan yang digunakan dalam analisis diskriminan model Altman adalah :
1. $X_{1}=$
Net Working Capital to Total Assets

Rasio ini menunjukan kemampuan perusahaan untuk menghasilkan modal kerja bersih dari keseluruhan total aktiva yang dimilikinya. Rasio ini dihitung dengan membagi modal kerja bersih dengan total aktiva. Modal kerja bersih diperoleh dengan cara aktiva lancar dikurangi dengan kewajiban lancar. Modal kerja bersih yang negatif kemungkinan besar akan mengahdapi masalah dalam menutupi kewajiban jangka pendeknya karena tidak tersedianya aktiva lancar yang cukup untuk menutupi kewajiban tersebut. Sebaliknya, perusahaan dengan modal kerja bersih yang bernilai positif jarang sekali menghadapi kesulitan dalam melunasi kewajibannya.

\begin{tabular}{|c|c|}
\hline Metode Perhitungan & $\frac{\text { Net Working capital }}{\text { total assets }}$ \\
\hline
\end{tabular}

\section{2. $\mathrm{X}_{2}=\quad$ Retained Earnings to Total Assets}

Rasio ini menunjukkan kemampuan perusahaan untuk menghasilkan laba ditahan dari total aktiva perusahaan. Laba ditahan merupakan laba yang tidak dibagikan kepada para pemegang saham. Dengan kata lain, laba ditahan menunjukkan berapa banyak pendapatan perusahaan yang tidak dibayarkan dalam bentuk dividen kepada para pemegang saham. Laba ditahan menunjukkan klaim terhadap aktiva, bukan aktiva per ekuitas pemegang saham. Perusahaan laba ditahan terjadi dikarenakan pemegang saham biasa mengizinkan perusahaan untuk menginvestasikan kembali laba yang tidak didistribusikan sebagai dividen. Dengan demikian, laba ditahan yang dilaporkan dalam neraca bukan merupakan kas dan 'tidak tersedia' untuk pembayaran dividen atau yang lain.

$$
\text { Metode Perhitungan }=\frac{\text { retained earnings }}{\text { Total assets }}
$$

\section{3. $X_{3}=\quad$ Earnings Before Interest and tax to Total Assets}

Rasio ini menunjukkan kemampuan perusahaan untuk menghasilkan laba dari aktiva perusahaan, sebelum pembayaran bunga dan pajak.

$$
\text { Metode Perhitungan }=\frac{E B I T}{\text { Total assets }}
$$


4. $X_{4}=$ Market Value of Equity to Book Value of Debt

Rasio ini menunjukkan kemampuan perusahaan untuk memenuhi kewajiban-kewajiban dari nilai pasar modal sendiri (saham biasa). Nilai pasr modal sendiri diperoleh dengan mengalikan jumlah lembar saham biasa yang beredar dengan harga pasar per lembar saham biasa. Nilai buku hutang diperoleh dengan menjumlahkan kewajiban lancar dengan kewajiban jangka panjang.

\section{Metode Perhitungan $=\frac{\text { Market Value of Equity }}{B 00 k \text { Value of Debt }}$ Book Value of Debt}

5. $X_{5}=\quad$ Sales to Total Assets

Rasio ini menunjukkan apakah perusahaan menghasilkan volume bisnis yang cukup dibandingkan investasi dalam total aktivanya. Rasio ini mencerminkan efisiensi manajemen dalam menggunakan keseluruhan aktiva perusahaan untuk menghasilkan penjualan dan mendapatkan laba.

$$
\text { Metode perhitungan }=\frac{\text { Sales }}{\text { Total assets }}
$$

\section{Populasi dan sampel}

Populasi yang digunakan dalam penelitian ini adalah sepuluh perusahaan properti di Indonesia yang terdapat di Bursa Efek Jakarta (BEJ). Kesepuluh perusahaan properti di Bursa Efek Jakarta(BEJ) yaitu PT. Lippo Karawaci Tbk., PT. Summarecon Agung Tbk., PT. Ciputra surya Tbk., PT. Roda Panggoan Harapan Tbk., PT. Bintang Semestaraya Tbk., PT. Duta Anggada Realty Tbk., PT. Duta PertiwiTbk., PT. Krida Perdana Indahgraha Tbk. Dan PT. Lamicitra Nusantara Tbk.

\section{Sumber Data Dan Teknik Pengambilan Data}

Data-data penelitian merupakan data sekunder yang diperoleh secara langsung dari Bursa Efek Jakarta ( BEJ) berupa laporan keuangan perusahaan selama periode 2001-2005 dan Lembaga IImu Pengetahuan Indonesia (LIPI). Penelitian ini menggunakan metode pengambilan sampel secara acak sederhana atau simple random sampling karena memberikan peluang yang sama bagi setiap unsur atau populasi untuk dipilih menjadi anggota sampel. Metode ini relatif sederhana karena hanya memerlukan satu tahap prosedur pemilihan sampel, setiap elemen populasi secara independen mempunyai probabilitas dipilih satu kali.

\section{Alat Analisis Data}

Penelitian ini akan menggunakan analisa potensi kebangkrutan perusahaan dengan menggunakan metode Altman sebagai alat analisis datanya. Untuk analisis potensi kebangkrutan atau untuk memprediksi kemungkinan kebangkrutan pada perusahaan propertibakan menggunakan metode yang ditemukan Altman yang dikenal dengan Z-Score. Dengan menggunakan metode Altman ini maka kita akan dapat memprediksikan kemungkinan terjadinya kebangkrutan pada sepuluh perusahaan properti.

Dari data laporan keuangan perusahaan akan dianalisis dengan menggunakan beberapa rasio-rasio keuangan yang dianggap dapat memprediksi kebangkrutan sebuah perusahaan. Beberapa rasio keuangan yang mendeteksi likuiditas, profitabilitas, dan aktivitas perusahaan yang akan menghasilkan rasio-rasio atau angka-angka yang akan diproses lebih lanjut dengan formula Altman. Data atau hasil perhitungan kemudian akan dianalisis lebih jauh lagi dengan menggunakan sebuah formula yang ditemukan Altman yaitu :

$$
Z=1,2 X_{1}+1,4 X_{2}+3,3 X_{3}+0,6 X_{4}+1,0 X_{5}
$$

Dimana:

X1 = Net Working Capital / Total Assets

$\mathrm{X} 2$ = Retained Earnings $/$ Total Assets

$\mathrm{X} 3$ = Earnings Before Interest and Tax / Total Assets

X4 = Market Value of Equity / Book Value of Debt

X5 = Sales/Total Assets

Kondisi ini dapat dilihat dari nilai Z-Score nya. Jika :

1. Untuk nilai Z-Score lebih kecil atau sama dengan 1,81 , berarti perusahaan mengalami kesulitan keuangan dan resiko tinggi.

2. Untuk nilai Z-Score antara 1,81 sampai 2,99 maka perusahaan dianggap berada pada daerah abu-abu (Grey Area). Pada kondisi ini, perusahaan mengalami masalah keuangan yang harus ditangani dengan penanganan manajemen yang tepat. Kalau terlambat dan tidak tepat penangananya, maka perusahaan dapat mengalami kebangkrutan. Jadi pada grey area ini ada kemungkinan perusahaan bangkrut dan ada pula yang tidak. Tinggal bagaimana pihak manajemen perusahaan dapat segera mengambil tindakan untuk segera mengatasi masalah yang dialami oleh perusahaan. 
3. Untuk nilai Z-Score lebih besar dari 2,99 , memberikan penilaian bahwa perusahaan berada dalam keadaan yang sangat sehat sehingga kemungkinan kebangkrutan sangat kecil terjadi.

\section{HASIL DAN PEMBAHASAN}

Analisis Variabel-Variabel Diskriminan Model Altman Pada PT. Lippo Karawaci Tbk.

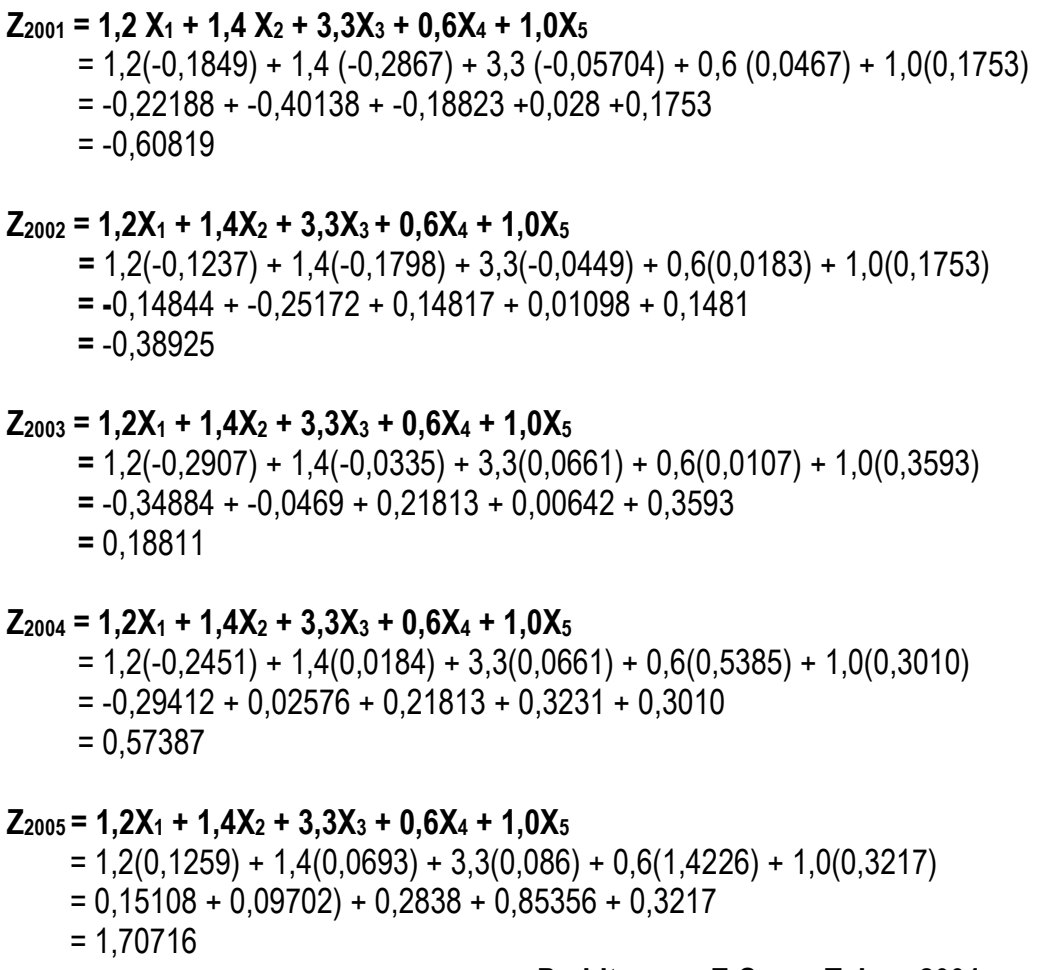

Perhitungan Z-Score Tahun 2001

\begin{tabular}{|l|r|l|}
\multicolumn{1}{|c|}{ Perusahaan } & Z-Score 2001 & \multicolumn{1}{c|}{ Hasil Analisis } \\
\hline PT. Lippo Karawaci & -0.6081 & Prediksi bangkrut \\
\hline PT. Summarecon Agung & 1.4896 & Prediksi bangkrut \\
\hline PT. Ciputra Surya & 0.6518 & Prediksi bangkrut \\
\hline PT. Roda Panggon Harapan & 2.8561 & Prediksi bangkrut/tidak \\
\hline PT. Bintang Mitra Semestaraya & 0.6807 & Prediksi bangkrut \\
\hline PT. Ciptojaya Kontrindoreksa & 4.1128 & Prediksi sehat \\
\hline PT. Duta anggada realty & -3.0505 & Prediksi bangkrut \\
\hline PT. Duta pertiwi & 0.5723 & Prediksi bangkrut \\
\hline PT. Kridaperdana Indahgraha & 2.653 & Prediksi bangkrut \\
\hline PT. Lamicitra Nusantara & 2.1908 & Prediksi bangkrut \\
\hline
\end{tabular}

(Sumber : Diolah penulis, 2006)

Perhitungan Z-Score Tahun 2002

\begin{tabular}{|c|c|c|}
\hline Perusahaan & Z-Score 2002 & Hasil Analisis \\
\hline PT. Lippo Karawaci & -0.3892 & Prediksi bangkrut \\
\hline PT. Summarecon Agung & 1.5187 & Prediksi bangkrut \\
\hline PT. Ciputra Surya & 0.981 & Prediksi bangkrut \\
\hline PT. Roda Panggon Harapan & 15.6501 & Prediksi sehat \\
\hline
\end{tabular}




\begin{tabular}{|l|r|l|}
\hline PT. Bintang Mitra Semestaraya & 0.3559 & Prediksi bangkrut \\
\hline PT. Ciptojaya Kontrindoreksa & 4.7342 & Prediksi sehat \\
\hline PT. Duta anggada realty & -2.9958 & Prediksi bangkrut \\
\hline PT. Duta pertiwi & 0.8755 & Prediksi bangkrut \\
\hline PT. Kridaperdana Indahgraha & 1.7054 & Prediksi bangkrut \\
\hline PT. Lamicitra Nusantara & 1.337 & Prediksi bangkrut \\
\hline
\end{tabular}

(Sumber : Diolah penulis, 2006)

Perhitungan Z-Score Tahun 2003

\begin{tabular}{|l|r|l|}
\multicolumn{1}{|c|}{ Perusahaan } & Z-Score 2003 & \multicolumn{1}{c|}{ Hasil Analisis } \\
\hline PT. Lippo Karawaci & 0.1881 & Prediksi bangkrut \\
\hline PT. Summarecon Agung & 1.4286 & Prediksi bangkrut \\
\hline PT. Ciputra Surya & 1.3383 & Prediksi bangkrut \\
\hline PT. Roda Panggon Harapan & 6.2431 & Prediksi sehat \\
\hline PT. Bintang Mitra Semestaraya & 0.5352 & Prediksi bangkrut \\
\hline PT. Ciptojaya Kontrindoreksa & 4.9692 & Prediksi sehat \\
\hline PT. Duta anggada realty & -2.8082 & Prediksi bangkrut \\
\hline PT. Duta pertiwi & 0.954 & Prediksi bangkrut \\
\hline PT. Kridaperdana Indahgraha & 1.4022 & Prediksi bangkrut \\
\hline PT. Lamicitra Nusantara & 0.7455 & Prediksi bangkrut \\
\hline
\end{tabular}

(Sumber : Diolah penulis, 2006)

Perhitungan Z-Score Tahun 2004

\begin{tabular}{|l|r|l|}
\hline \multirow{2}{*}{ Perusahaan } & Z-Score $\mathbf{2 0 0 4}$ & \multicolumn{1}{|c|}{ Hasil Analisis } \\
\hline PT. Lippo Karawaci & 0.5738 & Prediksi bangkrut \\
\hline PT. Summarecon Agung & 2.041 & Prediksi bangkruttidak \\
\hline PT. Ciputra Surya & 1.628 & Prediksi bangkrut \\
\hline PT. Roda Panggon Harapan & 4.1333 & Prediksi sehat \\
\hline PT. Bintang Mitra Semestaraya & 0.5183 & Prediksi bangkrut \\
\hline PT. Ciptojaya Kontrindoreksa & 7.5192 & Prediksi sehat \\
\hline PT. Duta anggada realty & -2.9101 & Prediksi bangkrut \\
\hline PT. Duta pertiwi & 0.9483 & Prediksi bangkrut \\
\hline PT. Kridaperdana Indahgraha & 2.5422 & Prediksi bangkruttidak \\
\hline PT. Lamicitra Nusantara & 0.8407 & Prediksi bangkrut \\
\hline
\end{tabular}

(Sumber : Diolah penulis, 2006)

Perhitungan Z-Score Tahun 2005

\begin{tabular}{|l|r|l|}
\multicolumn{1}{|c|}{ Perusahaan } & Z-Score 2005 & \multicolumn{1}{c|}{ Hasil Analisis } \\
\hline PT. Lippo Karawaci & 1.7071 & Prediksi bangkrut \\
\hline PT. Summarecon Agung & 2.242 & Prediksi bangkruttidak \\
\hline PT. Ciputra Surya & 2.6574 & Prediksi bangkrut/tidak \\
\hline PT. Roda Panggon Harapan & 8.6746 & Prediksi sehat \\
\hline PT. Bintang Mitra Semestaraya & 0.9632 & Prediksi bangkrut \\
\hline PT. Ciptojaya Kontrindoreksa & 11.072 & Prediksi sehat \\
\hline PT. Duta anggada realty & -0.0332 & Prediksi bangkrut \\
\hline PT. Duta pertiwi & 1.0168 & Prediksi bangkrut \\
\hline PT. Kridaperdana Indahgraha & 3.1674 & Prediksi sehat \\
\hline PT. Lamicitra Nusantara & 0.996 & Prediksi bangkrut \\
\hline
\end{tabular}

(Sumber : Diolah penulis, 2006)

Perhitungan Z-Score Dengan Menggunakan Excel 

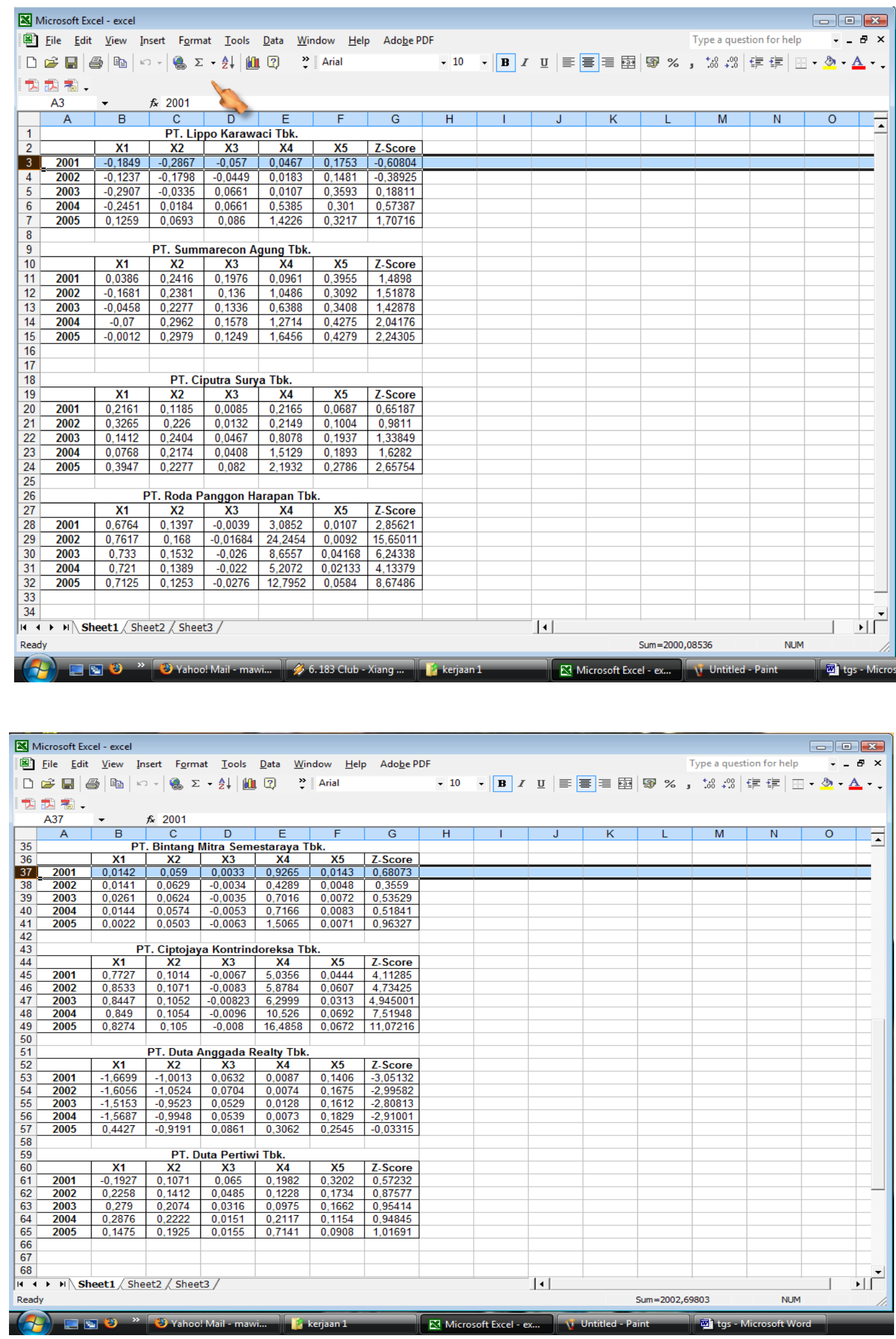


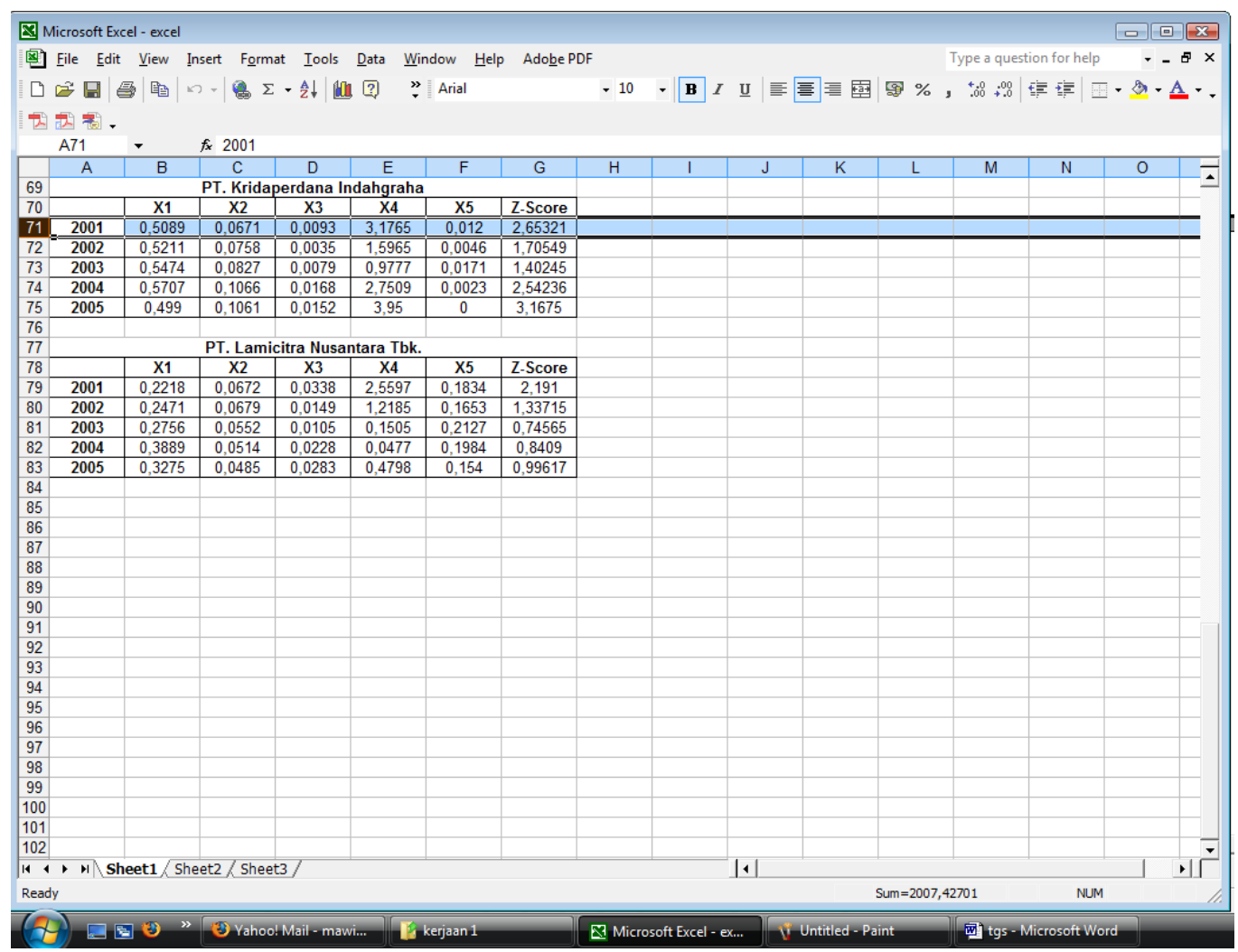

PENUTUP

Berdasarkan analisis dan pembahasan yang telah dilakukan pada BAB 4, maka dapat disimpulkan bahwa :

- $\quad$ PT. Lippo Karawaci Tbk. diindikasikan sedang menghadapi ancaman kebangkrutan yang serius. Hal ini dapat dilihat dari nilai Z perusahaan yang pada tahun 2001, 2002, 2003, 2004 dan 2005 berada dibawah 1.81, yaitu sebesar -0.6081 pada tahun 2001, -0.3892 pada tahun 2002, 0.1881 pada tahun 2003, 0.5738 pada tahun 2004 dan 1.7071 pada tahun 2005. Peningkatkan nilai Z perusahaan menunjukkan bahwa perusahaan sedang berusaha untuk memperbaiki kinerja keuangannya.

- $\quad$ PT. Summarecon Agung Tbk. diindikasikan berada pada daerah abu-abu, perusahaan sedang menghadapi masalah keuangan yang cukup serius, dimana apabila perusahaan tidak melakukan perbaikan yang radikal, perusahaan mungkin akan menghadapi ancaman kebangkrutan dalam jangka waktu dua tahun. Hal ini ditunjukkan oleh nilai Z nya yang berada dibawah 2.99, yaitu sebesar 1.4896 pada tahun 2001, 1.5187 pada tahun 2002, 1.4296 pada tahun 2003, 2.041 pada tahun 2004 dan 2.242 pada tahun 2005. Peningkatan nilai Z perusahaan menunjukkan bahwa perusahaan juga sedang beursaha untuk memperbaiki kinerja keuangannya.

- $\quad$ PT. Ciputra Surya Tbk. diindikasikan sedang menghadapi masalah keuangan yang cukup serius, hal ini ditunjukkan oleh nilai Z perusahaan yang masih berada dibawah 2.99 yaitu sebesar 0.6518 pada tahun $2001,0.981$ pada tahun 2002, 1.3383 pada tahun 2003, 1.628 pada tahun 2004 dan 2.6574 pada tahun 2005. Peningkatan Z perusahaan menunjukkan bahwa perusahaan juga sedang berusaha memperbaiki kinerja keuangannya.

- $\quad$ PT. Roda Panggon Harapan Tbk. diindikasikan dalam keadaan yang sehat, hal ini ditunjukkan oleh nilai Z perusahaan yang sudah lebih dari 2.99 yaitu dari 2.8561 pada tahun 2001, 15.6501 pada tahun 2002, 6.2431 pada tahun 2003, 4.1333 pada tahun 2004, dan 8.6746 pada tahun 2005. Meskipun Z perusahaan masih turun naik tapi nilai Z nya sudah lebih dari 2.99.

- $\quad$ PT. Bintang Mitra semestaraya Tbk. diindikasikan sedang menghadapi ancaman kebangkrutan yang serius. Hal ini dapat dilihat dari nilai Z perusahaan yang pada tahun 2001, 2002, 2003, 2004 dan 2005 berada dibawah 1.81, yaitu sebesar 0.6807 pada tahun 2001, 0.3559 pada tahun 2002, 0.5352 pada tahun 2003, 0.5183 pada tahun 2004 dan 0.9632 pada tahun 2005. Peningkatan nilai Z perusahaan menunjukkan bahwa perusahaan sedang memperbaiki kinerja keuangannya.

- $\quad$ PT. Ciptojaya Kontrindoreksa Tbk. diindikasikan dalam keadaan sehat, hal ini dapat dilihat dari nilai Z perusahaan yang lebih dari 2.99 yaitu 4.1128 pada tahun 2001, 4.7342 pada tahun 2002, 4.9692 pada tahun $2003,7.5192$ pada tahun 2004 dan 11.072 pada tahun 2005.

- PT. Duta Anggada Realty Tbk. diindikasikan sedang menghadapi ancaman kebangkrutan yang sangat serius. Hal ini dapat dilihat dari nilai Z perusahaan yang masih bernilai negatif yaitu bernilai -3.0505 pada tahun $2001,-2.9958$ pada tahun 2002, -2.8082 pada tahun 2003, -2.9101 pada tahun 2004 dan -0.0332 pada tahun 2005. 
- PT. Duta Pertiwi Tbk. diindikasikan sedang menghadapi masalah keuangan yang sangat serius, hal ini ditunjukkan oleh nilai Z perusahaan yang masih berada dibawah 1,81 yaitu bernilai 0.5723 pada tahun $2001,0.8755$ pada tahun 2002 , 0.954 pada tahun 2003, 0.9483 pada tahun 2004 dan 1.0168 pada tahun 2005. Peningkatan Z perusahaan menunjukkan bahwa perusahaan juga sedang berusaha memperbaiki kinerja keuangannya.

- $\quad$ PT. Kridaperdana Indahgraha Tbk. diindikasikan bahwa perusahaan berada dalam kondisi yang sehat, hal ini dapat dilihat dari nilai Z perusahaan yang lebih besar dari 2.99 yaitu bernilai 2.653 pada tahun 2001, 1.7054 pada tahun 2002, 1.4022 pada tahun 2003, 2.5422 pada tahun 2004 dan 3.1674 pada tahun 2005.

- PT. Lamicitra Nusantara Tbk. diindikasikan sedang menghadapi masalah keuangan yang sangat serius, hal ini ditunjukkan oleh nilai Z perusahaan yang masih berda dibawah 1.81 yaitu bernilai 2.1908 pada tahun 2001, 1.337 pada tahun 2002, 0.7455 pada tahun 2003, 0.8407 pada tahun 2004 dan 0.996 pada tahun 2005. Peningkatan Z perusahaan menunjukkan bahwa perusahaan juga sedang berusaha memperbaiki kinerja keuangannya.

\section{REFERENSI}

Adnan, Muhamad A \& Taufiq, Muhamad I. (2001). Analisis ketepatan Prediksi Metode

Altman Terhadap Terjadinya Likuiditas Pada Lembaga Perbankan. Jurnal Ekonomi \& Auditing Volume 5 No.2 Desember. Yogyakarta: Fakultas Ekonomi Universitas Islam Indonesia. Yogyakarta.

Emery, Douglas R., et al (2004). Corporate Financial Management. 2nd Edition. New Jersey : pearson education Inc.

Harahap, Sofyan Syafri. (2006). Analisis Kritis Atas Laporan Keuangan. Jakarta : PT. RajaGrafindo Persada.

Kuswandi. (2004). Cara Mudah Memahami Angka-angka dan Manajemen Keuangan Bagi Orang Awam. Jakarta : PT. Elek Media Komputindo

Lontoh, F \& Lindrawati. (2004). Manajemen Laba Dalam Persepsi Etis Akuntan Dijawa Timur. Jurnal widya Manajemen \& Akuntansi Volume 4 No. 1 April. Surabaya : Fakultas Ekonomi Universitas Katolik Widya Mandala, Surabaya.

Munawir, S. (2004). Analisa Laporan Keuangan, Edisi keempat. Yogyakarta: Liberty. 